\title{
Physiological Adaptation and Biomass Production of Macroptilium bracteatum Inoculated with AMF in Drought Condition
}

\author{
S. Sowmen ${ }^{a}$ *, L. Abdullah ${ }^{\text {, }}$ P. D. M. H. Karti ${ }^{\text {, }}$ \& D. Sopandie ${ }^{c}$ \\ a Major Program of Animal Nutrition and Feed Science, Graduate School, Bogor Agricultural University \\ ${ }^{b}$ Faculty of Animal Science, Bogor Agricultural University \\ Jln. Agatis, Kampus IPB Darmaga Bogor 16680, Indonesia \\ 'Faculty of Agriculture, Bogor Agricultural University \\ Jln. Meranti Kampus IPB Darmaga, Bogor 16680, Indonesia \\ (Received 02-05-2012; accepted 02-08-2012)
}

\begin{abstract}
ABSTRAK
Penelitian ini bertujuan untuk mengetahui pengaruh kekeringan dan inokulasi mikoriza arbuskular (MA) terhadap adaptasi fisiologi dan produksi biomassa dari Macroptilium bracteatum. Penelitian ini menggunakan rancangan acak lengkap dengan empat perlakuan, yaitu: M0 ( tanpa MA + disiram), M1 (MA + disiram), M2 (tanpa MA + tidak disiram), dan M3 (MA + tidak disiram), dengan 3 ulangan. Peubah yang diuji adalah kandungan air tanah, potensial air daun, kadar air relatif daun, prolin daun, karbohidrat terlarut daun, serta bobot kering akar dan tajuk. Data dianalisis dengan ANOVA dan perbedaan antar perlakuan diuji lanjut dengan DMRT. Perlakuan kekeringan (M2 dan M3) secara signifikan $(P<0,05)$ menurunkan kandungan air tanah, potensial air daun, kandungan air relatif daun, dan meningkatkan kandungan prolin daun, sedangkan pada data bobot kering akar dan tajuk, terlihat bahwa perlakuan M1 berbeda nyata $(\mathrm{P}<0,05)$ dengan perlakuan M0, M2, dan M3. Kandungan karbohidrat terlarut daun, perlakuan M0 dan M2 berbeda nyata $(P<0,05)$ dengan perlakuan M1 dan M3. Mikoriza pada M. bracteatum lebih efektif saat tercekam kekeringan. Salah satu mekanisme ketahanan kekeringan dari $M$. bracteatum adalah dengan akumulasi senyawa osmotik prolin. Prolin dapat dijadikan sebagai indikator ketahanan kekeringan pada tanaman leguminosa.
\end{abstract}

Kata kunci: mikoriza, kekeringan, Macroptilium bracteatum, prolin, potensial air

\section{ABSTRACT}

The objective of this experiment was to evaluate the effect of drought stress and mycorrhizal inoculation on physiological adaptation and biomass production of Macroptilium bracteatum. This experiment was arranged in completely randomized design with four treatments: M0 (no AM + watered), M1 (AM + watered), M2 (no AM + drought), and M3 (AM + drought) with three replicates. The observed variables were soil water content, leaf water potential, leaf relative water content, leaf proline, leaf water soluble carbohydrate (WSC), root and shoot dry weight. Data were analyzed by ANOVA and differences between treatments were tested by DMRT. Drought treatments (M2 and M3) significantly $(\mathrm{P}<0.05)$ decrease soil water content, leaf water potential, leaf relative water content and increased the leaf proline content. The result in root and shoot dry weight appear that M1 treatment was significantly different $(\mathrm{P}<0.05)$ with treatment M0, M2, and M3. For leaf WSC, M0 and M2 treatments were significantly different $(\mathrm{P}<0.05)$ with treatment M1 and M3. It is concluded that mycorrhiza inoculation was more effective on $M$. bracteatum, in drought stress. One mechanism of drought resistance of $M$. bracteatum is the accumulation of osmotic compounds proline. Therefore, proline can be used as an indicator of drought resistance in leguminous plants.

Key words: mychorriza, drought stress, Macroptilium bracteatum, proline, water potential

\footnotetext{
* Corresponding author:

E-mail: simel.hanna@gmail.com
} 


\section{INTRODUCTION}

One of the major problems to sustain ruminant production is availability of forage. This is mainly due to lack of forage production during dry season. The productivity of forage plants strongly depends on availability of soil water. Lack of soil water causes plants undergo morphological and physiological disorders, and in turn their growth and productivity will be hampered. The response of plants by showing injury appearance indicates drought stress. It makes difficulties in maintaining forage production and quality. Drought stress in plants is greater than water absorption due to rate of evapotranspiration and short of water supply in the rhizosphere (Taiz \& Zeiger, 2002).

Utilization of mycorrhizae may assist plants to overcome drought stress. Mycorrhizal fungi function in improving the nutritional status of plants and increase plant resistance to drought (Karti, 2004). The ability of mycorrhizal fungi to encounter drought stress probably due to several mechanisms: (1) increase of nutrient concentration in rhizosphere, (2) expand the area of plant roots thereby increasing the efficiency of water absorption, (3) increase absorption of nutrients $\mathrm{P}$ and other nutrients, (4) enable rapid plant defense system, (5) protect plants from oxidative damage due to drought (Song, 2005).

Drought stress induces proline and soluble sugar in potato leaves (Masoudi et al., 2011), in 49 pea cultivars (Shancez et al., 1998), citrus (Wu et al., 2007), Medicago truncatula and M. laciniata (Yousfi et al., 2010). Proline is an important amino acid in plant under drought stress that prevents oxidation of cells from inside. It also regulates osmotic pressure of plant under drought stress for absorbing water (Bhosale \& Shinde, 2011). The purpose of this study was to assess the effect of drought treatment and the inoculation of mycorrhizae on biomass production and physiological adaptation of Macroptilium bracteatum and the effectiveness of mycorrhizal in drought stress plants.

\section{MATERIALS AND METHODS}

M. bracteatum seeds were obtained from Assessment Institute for Agriculture Technology Naibonat, East Nusa Tenggara province, Indonesia. The seed was sown in polibag, and after one month it was transferred to a pot. AMF inoculation used Mycofer that contains Gigaspora margarita and Glomus manihotis, commercial product produced by Laboratory of Forest Biotechnology, PAU, Bogor Agricultural University. Five kg pot capacity used in this study was filled with soil- manure in ratio of 9:1.

\section{Transplanting and Drought Treatment}

The soils were divided into four groups of mycorrhizal and drought combination treatments, consisting of soils with mycorrhizae and watered (M0), soils without mycorrhizae and watered (M1), soils without mycorrhizae and drought (M2), and soil with mycorrhizae and drought (M3). For pot treatments with mycorrhizae, 20 $\mathrm{g}$ of Mycofer was applied. One month seedlings were transplanted to each pot, and grown for one month. The soils remained was moisted $(60 \%$ water holding capacity) by daily watering. This was done before drought treatment to give chance for plants to survive. Weeding was done manually every week. The plants were trimmed at $30 \mathrm{~cm}$ above ground in order to uniform the plants.

Before the drought treatment started, all of the soil groups were watered in saturated level, the pots were covered with polyethylene plastic that has a hole in the centre as space for standing plants, and the plastics were sealed to avoid evaporation. However treatments M2 and M3 were dried until the observation finished. Observation began a day after treatment, and repeated every $4 \mathrm{~d}$ until the plants were wilted permanently (reach wilting permanent point), and the plants were harvested.

\section{Experimental Design and Statistical Analysis}

The experiment was set up in a completely randomized design with four combination treatments, M0 as control, M1, M2, and M3 with 3 replications. The data were statistically analyzed by analysis of variance (ANOVA), and the means were tested by using Duncan Multiple Range Test at 5\% level of significance differences.

\section{Parameters}

Soil water content. Soil moisture content was measured every $4 \mathrm{~d}$ during treatment and tested manually based on Foth (1984).

Water potential. Leaf water potential were tested using Dewpoint Potential Meter WP4 (ICT International, 2010). Leaf water potential was measured every $4 \mathrm{~d}$ during treatment.

Relative water content (RWC). Leaf RWC analysis was measured based on the method of Slatyer \& Barrs (1965). RWC was calculated from the following equation:

\section{$\mathrm{RWC}=(\mathrm{FW}-\mathrm{DW}) /(\mathrm{TW}-\mathrm{DW}) \times 100 \%$}

Leaf prolin content. Proline in leaf was analyzed every 8 $\mathrm{d}$ based on the method of Bates et al. (1973). A $15 \mathrm{~cm}$ fresh leaf was frozen in liquid nitrogen and quickly ground to a powder $(1 \mathrm{~min})$. About $100 \mathrm{mg}$ of ground samples were placed in a micro tube, added with $1.3 \mathrm{ml}$ sulfosalicylic acid 3\%, vortexed, and centrifuged at $12.000 \mathrm{rpm}$ for $10 \mathrm{~min}$. A $200 \mu \mathrm{l}$ supernatant was placed in a new tube, treated with $200 \mu \mathrm{l}$ ninhidrilacid solution $(0.125 \mathrm{~g}$ ninhidril, $3 \mathrm{ml}$ of glacial acetic acid, $2 \mathrm{ml} 6 \mathrm{M}$ phosphoric acid (with agitation and heating), and again shaken with vortex machine. The mixture was incubated in waterbath at a temperature of $100{ }^{\circ} \mathrm{C}$ for $1 \mathrm{~h}$, cooled in ice to stop the reaction, inserted into the tube with $400 \mu \mathrm{l}$ of toluene, and vortexed. A total of $100 \mu \mathrm{l}$ of red liquid from the reaction products were mixed with $900 \mu \mathrm{l}$ of toluene, and spectro- 
photometrically determined at $520 \mathrm{~nm}$. Concentration of proline was determined by comparing with a standard curve prepared using pure proline materials.

Water soluble carbohydrate (WSC). WSC analysis was conducted based on Dubois et al. (1956) and modified according to Buysse \& Merckx (1993). About 20-30 mg of dried leaves or dried root were extracted for $15 \mathrm{~min}$ in 10 $\mathrm{ml}$ of the boiling water, and centrifuged at $3500 \mathrm{rpm}$ for $10 \mathrm{~min}$. The supernatant was collected and adjusted to $50 \mathrm{ml}$. One $\mathrm{ml}$ of supernatant was placed in a tube and added with $1 \mathrm{ml}$ phenol (18\%) and $5 \mathrm{ml}$ of concentrated sulfuric acid. The mixture was shaken and determined by spectrometer at wave length $490 \mathrm{~nm}$.

Shoot and root dry weight. Shoot and root dry weight measurements were performed at harvesting time. After harvesting, shoot and root were dried up in the oven at $70{ }^{\circ} \mathrm{C}$ for $48 \mathrm{~h}$.

\section{RESULTS AND DISCUSSION}

\section{Physiological Adaptation}

Soil water content. Soil water content decreased during observation. Soil water content at the end of treatment was significantly different $(\mathrm{P}<0.05)$ (Figure 1$)$. Soil water content in treatment $\mathrm{M} 0$ showed no significant difference to $\mathrm{M} 1$, but it was significantly difference $(\mathrm{P}<0.05)$ with M2 and M3. Drought stressed with AM plants (M3) increased in soil water content $(26 \%)$ as compared to non AM plants. Soil water content of AM plants (32.47\%) in drought condition was higher than non AM plants (25.8\%) (Figure 1). This could be due to the ability of mycorrhizae in plant roots to bind water to conserve soil moisture. This is consistent with the results of $\mathrm{Wu}$ et al. (2008), AM fungus colonization enhanced plant growth under drought stress indirectly by affecting the soil moisture retention via glomalin's effect on soil water stable agregates. Mycorrhizal inoculation improved drought resistance of the Marigold plants as a consequence of enhancing nutritional status, especially $\mathrm{P}$ and water status of the plants. Mycorrhizal fungi colonization alleviates the stress with water holding (Asrar \& Elhindi, 2011). Mycorrhiza can alter root morphology, allowing the plants to explore a greater soil volume and acquire a greater share of the soil resources (ie. water and nutrient) in comparison with non mycorrhizal plants (Kothari et al., 1990). Some arbuscular mycorrhizal fungi are ecologically distinct in their distribution with/and their species richness can be positively related to soil moisture content (Beauchamp et al., 2006).

Leaf water potential. Leaf water potential decreased significantly $(\mathrm{P}<0.05)$ with increasing drought durations in this experiment (Figure 2). For each treatment, the leaf water potential decreased in the $4^{\text {th }} \mathrm{d}$ of drought. The water potential in drought treatments (M2 and M3) was more negative in the $8^{\text {th }}$ and $12^{\text {th }} \mathrm{d}$ and showed significant reduction at the end of the study (Figure 2). The results are in accordance with Martinez et al. (2007), water stress significantly decreased water potential at all varieties of mung bean. Drought stress decreased leaf water potential, but the decrease was larger in non AM plants (M2) than AM plants (M3). Mycorrhiza roles in improving the adaptability of plants to drought stress, strengthen the mechanism of osmoregulation in enhancing the adaptive capacity of plants with moderate drought stress (Hapsoh et al., 2006). The decrease in water potential was sufficient to avoid significant loss of water from the leaves of plant. Soil water depletion reduced leaf water potential and leaf osmotic potential at full turgor. The lowering of osmotic potential in water stressed leaves indicated that solute accumulation occurred. Tendency of forage legumes to maintain high leaf water potentials could be an example of a stress avoidance mechanism (Lannuci et al., 2002). But according to Rascio et al. (1994) osmotic adjustment, the lowering of osmotic potential by net solute accumulation in response to dehydration, assists the maintenance of turgor at lower water potentials, and it has been considered a beneficial drought tolerance mechanism in both the vegetative and reproductive phases of crop growth.

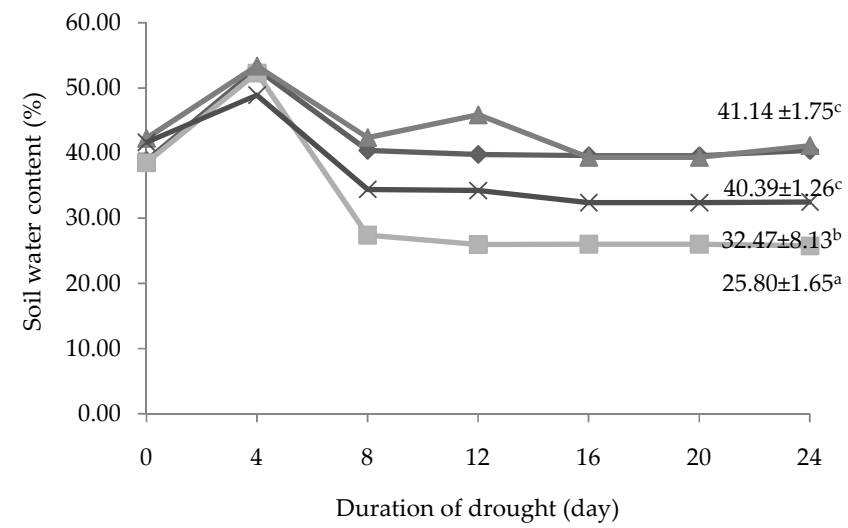

Figure 1 . The average soil water content (\%) in drought stressed treatments throughout the drought stress period. M0 $(--)=$ non $\mathrm{AM}+$ watered; M1 $(-\boldsymbol{\Delta}-)=\mathrm{AM}+$ watered; M2 $(-\mathbf{m}-)=$ non $\mathrm{AM}+$ drought; $\mathrm{M} 3(-\mathrm{x}-)=\mathrm{AM}+$ drought .

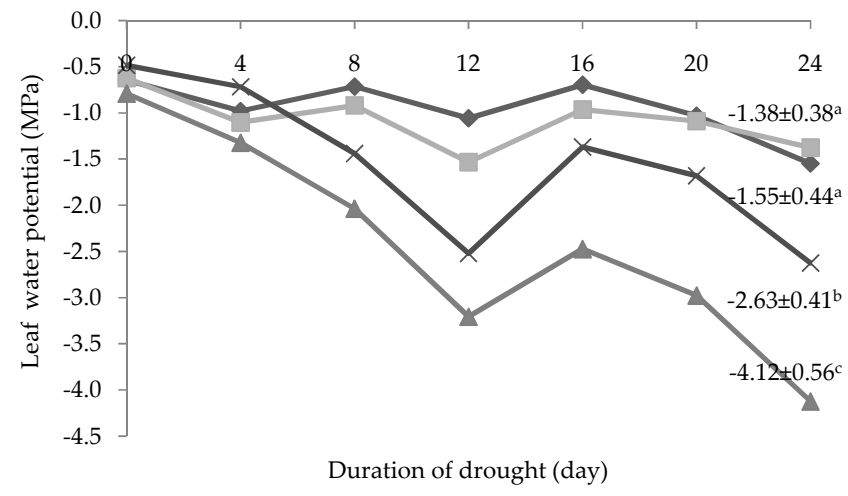

Figure 2. The average leaf water potential (MPa) in drought stressed treatments throughout the drought stress period. M0 $(--)=$ non $A M+$ watered; $M 1(-\boldsymbol{\Delta}-)=A M+$ watered; M2 (-m-)= non AM + drought; M3 (-x-)= AM + drought. 
Relative water content (RWC). RWC decreased significantly with increasing drought duration (Figure 3). AM plants had higher RWC values and significantly different than non AM plants $49.16 \%$ and $34.74 \%$, respectively. RWC related to water uptake by the roots as well as water loss by transpiration. Mycorrhizal inoculation increased RWC in citrus than without mycorrhizae (Wu \& Xia, 2006). At water stress condition, RWC values decreased in all types of maize (Efeoglu et al., 2009), Cotinus coggygria seed (Li et al., 2011), lentils (Chakherchaman et al., 2008), creeping bentgrass and velvet bentgrass (da Costa \& Huang, 2006), dragonhead (Rahbarian et al., 2010), rubber seed (Charloq \& Setiadi, 2005), wheat (Moaveni, 2011), rice (Pirdashti et al., 2009), tomato (Yuan et al., 2010). Decrease in RWC in leaves is affected by water shortages, an indication of a decrease in swelling pressure on plant cells and resulted in decreased growth (Gholinezhad et al., 2009). RWC decreased stress on the plant at any stage of growth in sorghum (Shao et al., 2008), and young bean (Stoyanov, 2005).

Relative water content (RWC) was significantly reduced under water stress condition. RWC may be attributed to differences in the ability to absorb more water from the soil and/or the ability to control water loss through stomata and RWC parameter can be used to select high yielding genotypes that maintain cell turgor under water stress environment to give relative high yield (Bayoumi et al., 2008). Relative water content is considered a measure of plant water status, reflecting the metabolic activity in tissues and used as a most meaningful index for dehydration tolerance (Anjum et al., 2011).

Proline. Levels of proline in the leaves were minor in control plants (M0) and M1 treatments, but in M2 and M3 treatments increased proportionally in response to drought stress (Figure 4). Proline increased considerably in leaves as a consequence of drought stress. Proline accumulation is the first response of plants exposed to water-deficit stress in order to reduce injury to cells (Anjum et al., 2011). Increase in the free proline content during water stress condition suggests that proline is one of the

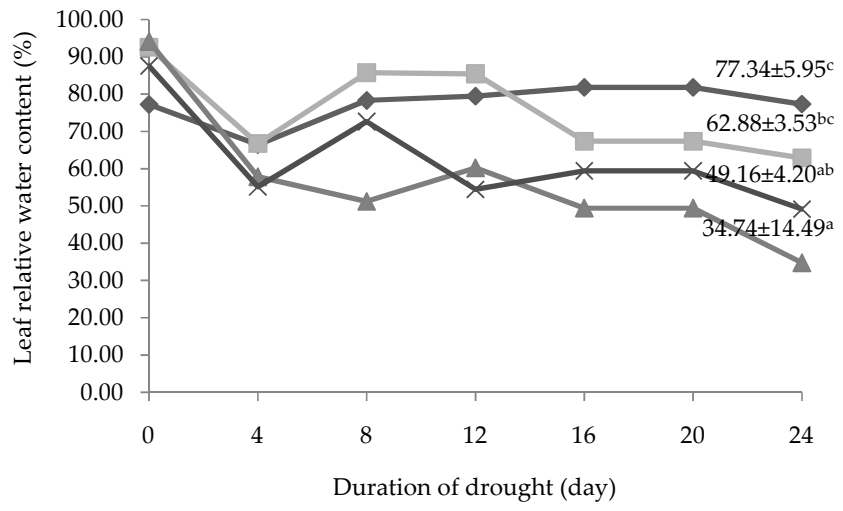

Figure 3. The average leaf relative water content (\%) in drought stressed treatments throughout the drought stress period. $\mathrm{M0}(--)=$ non $\mathrm{AM}+$ watered; $\mathrm{M} 1(-\boldsymbol{\Delta}-)=\mathrm{AM}+$ watered; M2 (-m-)= non AM + drought; M3 $(-x-)=$ AM + drought. common compatible osmolytes under water stress condition (Kumar et al., 2011).

Water stress significantly increased the plant proline accumulation (Verslues \& Sharman, 2010), canola (Din et al., 2011), maize (Khani \& Heidari, 2008), potatoes (Farhad et al., 2011), soybean (Hapsoh et al., 2006), beans (Shancez et al., 1998), tobacco (Yue et al., 2011). This is possible because the proline plays an important role in preventing / reducing loss caused by water shortage (Khani \& Heidari, 2008). Proline is the proteinogenic amino acids with the exception of conformational rigidity and essential for primary metabolism. Benefits of proline in plants are that proline is used for the synthesis of proteins, having a protective function as an osmolyte, and contributing to maintaining the redox balance. Proline can act as a signaling molecule to modulate mitochondrial functions, influence cell proliferation or cell death and trigger specific gene expression, which can be essential for plant recovery from stress (Szabados \& Savoure, 2009).

In this treatment, leaf proline content in drought condition was higher in non AM plants (M2) than AM plants (M3). Proline accumulation in plants without mycorrhizae was higher than plants with mycorrhizae during water stress (Vazquez et al., 2001; Sanchez et al., 2010; Wu \& Xia, 2006). Hapsoh et al. (2006), elevated levels of proline in plants as an osmotic regulator that involves the accumulation of soluble compounds. This increase is sufficient to lower the osmotic potential to maintain turgor remained positive following the decrease in tissue water potential. Proline accumulation in plants under drought is a result of the reciprocal regulation of two pathways; 1) increased expression of proline synthetic enzymes and 2) repressed activity of proline degradation. This leads to a proline cycle, the homeostasis of which depends on the physiological state of tissue (Khani \& Heidari, 2008).

Water soluble carbohydrate (WSC). Average of leaf WSC of M. bracteatum on drought and mycorrhiza treatments during the experiment was not significantly difference $(\mathrm{P}>0.05)$ between control $(\mathrm{M} 0)$ and drought treated

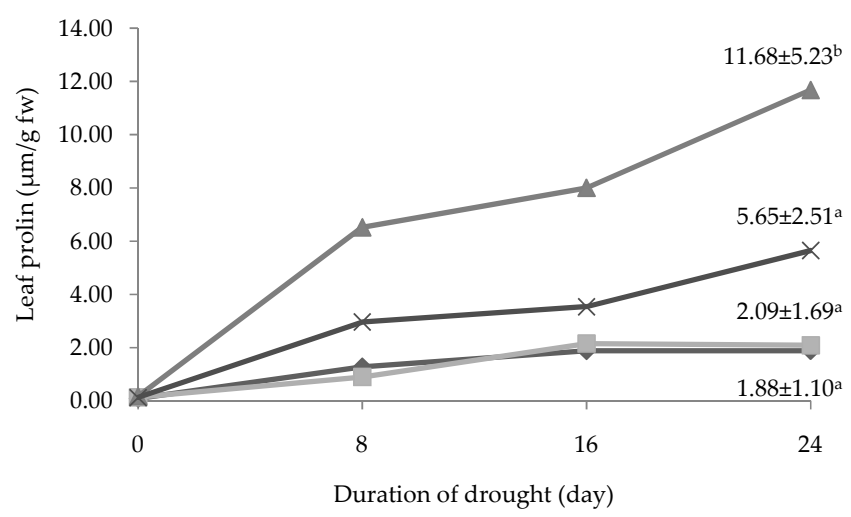

Figure 4. The average leaf proline content in drought stressed treatments throughout the drought stress period. M0 $(-\downarrow-)=$ non AM + watered; M1 (- $\mathbf{\Delta}-)=A M+$ watered; M2 $(-\mathbf{m})=$ non $\mathrm{AM}+$ drought; $\mathrm{M} 3(-\mathrm{x}-)=\mathrm{AM}+$ drought. 
plants (M2). The concentrations of soluble sugar in this treatment was significantly difference $(\mathrm{P}<0.05)$ between $\mathrm{AM}$ (M1 and M3) and non AM (M0 and M2) treatments (Figure 5). Leaf WSC concentrations were higher in inoculated mycorrhizal plants than non AM plants both in normal and drought conditions. This coincides with findings of Wu et al. (2007), AM plants accumulated more soluble sugars, soluble starch and total non structural carbohydrates in leaves and roots than non AM seedling regardless of soil water status. Lower accumulation of soluble sugars indicates that plants avoid drought more successfully and so have less need to osmotically adjust symplasm or osmoprotect enzyme, or shows less injury (Song, 2005). Based on the results, an increase in WSC content of the leaves are more affected by the presence of mycorrhizae and not affected by drought.

\section{Biomass Production}

Root and shoot dry weight. Root and shoot dry weight response were similar between treatments M0, M2 and M3, but were significantly difference $(\mathrm{P}<0.05)$ with $\mathrm{M} 1$ treatment (Figure 6a and 6b). Figure 6a shows AM treatment (M1) had lower root dry weight value (0.05 g/pot), and in drought condition (M3) was $64 \%$ higher $(0.14$ gram), but M3 had no significant difference ( $\mathrm{P}>0.05)$ compared to non AM treatments (M0 and M2). The increased in root dry mass ratio under drought stress in AM treatment observed here predicts that plants will react to a limited water availability with a relative increase in the flow of assimilates to the root leading to an increased in root dry mass ratio. When soil was dried, the water uptake by roots could not meet the high transpiration rates, therefore, the plants tried to maintain root growth and restrict leaf area expansion, which eventually led to a large decrease in leaf area per root dry mass (Liu \& Stutzel, 2004).

AM plants in normal condition (M1) had lower shoot dry weight (2.18 g/pot), but in drought condition (M3) shoot dry weight increased $51.66 \%$ (Figure 6b). There was no significant difference $(\mathrm{P}>0.05)$ between treatments M0, M2, and M3. These results were in contrast to Khan et al. (2008), that yield with respect to

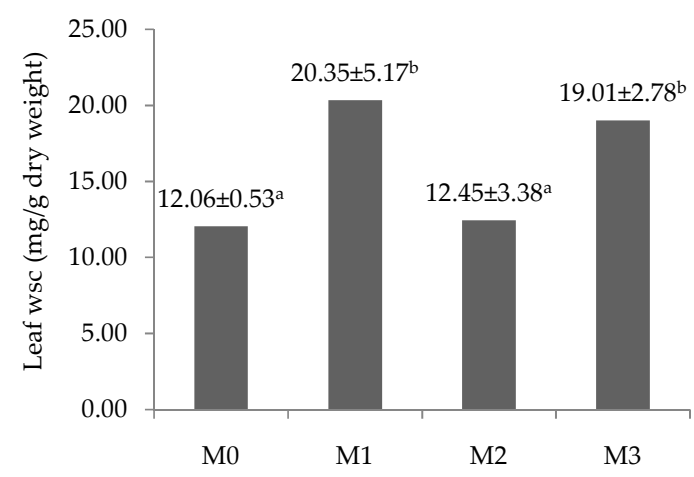

Figure 5. The average leaf water soluble carbohydrate content in drought stressed treatments (mg/g dry weight). $\mathrm{M} 0=$ non $\mathrm{AM}+$ watered; $\mathrm{M} 1=\mathrm{AM}+$ watered; $\mathrm{M} 2=$ non $\mathrm{AM}$ + drought; $\mathrm{M} 3=\mathrm{AM}+$ drought.
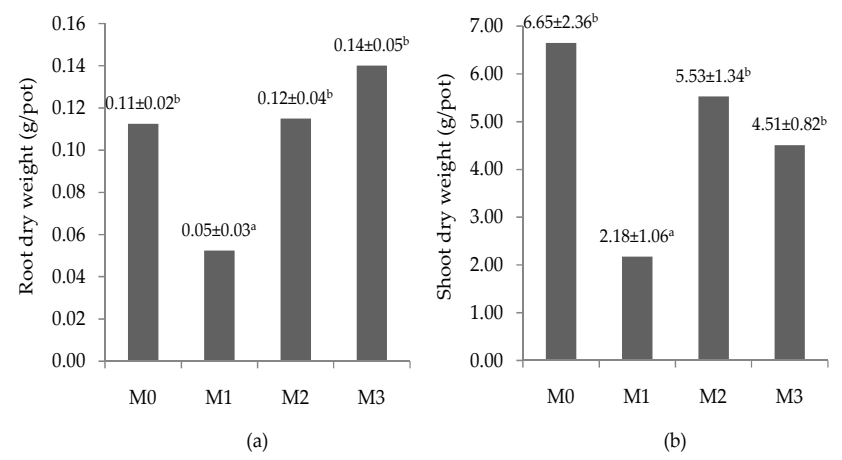

Figure 6. The average root dry weight (g/pot) (a) and shoot dry weight $(\mathrm{g} / \mathrm{pot})(\mathrm{b})$ in drought stressed treatments. M0= non $\mathrm{AM}+$ watered; $\mathrm{M} 1=\mathrm{AM}+$ watered; $\mathrm{M} 2=$ non $\mathrm{AM}$ + drought; $\mathrm{M} 3=\mathrm{AM}+$ drought.

shoot and root dry weight in dual VAM inoculation was significantly increased.

Based on these results, mycorrhizal inoculation was more effective in $M$. bracteatum during drought stress, whereas at normal condition mycorrhiza was not required by this plants, this is likely due to the genotype influence of this plants. This is in agreement with the results of Wilson \& Hartnett (1998) that annuals plants were generally not responsive to mycorrhizal colonization and were lower in percentage of root colonization than the perennial species. Plant growth responsiveness and $\mathrm{AM}$ root colonization were positively correlated for the non leguminous species, with this relationship being strongest for the cool-season grasses. In contrast, root colonization of prairie legumes showed a significant, but negative relationship to mycorrhizal growth responsiveness.

\section{CONCLUSION}

M. bracteatum was more effective inoculated with mycorrhizal when exposed to drought stress. One of the mechanisms of drought resistance in M. bracteatum is the accumulation of leaf proline.

\section{REFERENCES}

Anjum, S. A., X. Y. Xie, L. C. Wang, M. F. Saleem, C. Man, \& W. Lei. 2011. Review: Morphological, physiological and biochemical responses of plants to drought stress. African J. Agric. Res. 6: 2026-2032.

Asrar, A. W. \& K. M. Elhindi. 2011. Alleviation of drought stress of Marigold (Tagetes erecta) plants by using arbuscular mycorrhizal fungi. Saudi Journal Biological Sciences 18: 93-98.

Bates, L. S. 1973. Rapid determination of free proline for water stress studies. Plant Soil 39: 205-207. http://dx.doi. org/10.1007/BF00018060

Beauchamp, V. B., J. C. Strombrg, \& J. C. Stutz. 2006. Arbuscular mycorrhizal fungi associated with Populus salix stands in a semiarid riparian ecosystem. New Phytologyst 170: 369-380. http://dx.doi.org/10.1111/ j.1469-8137.2006.01668.x

Bhosale, K. S. \& B. P. Shinde. 2011. Influence of arbuscular mycorrhizal fungi on proline and chlorophyll content in Zingiber Officinale Rosc grown under water stress. Indian J. 
Fundamental and Applied Life Sciences 1: 172-176.

Buysse, J. \& J. M. Merckx. 1993. An improved colorimetric method to quantify sugar content of plant tissue. J. Experimental Botany 44: 1627-1629. http://dx.doi.org/10.1093/ $\mathrm{jxb} / 44.10 .1627$

Chakherchaman, S. H. A., H. K. Arbat, M. Yarnia, H. Mostafaei, D. Hassanpanah, M.R. Dadashi, \& R. Easazadeh. 2008. Study on relations between relative water content, cell membrane stability and duration of growth period with grain yield of Lentil Genotypes under drought stress and non stress conditions. International Meeting on Soil Fertility Land Management and Agroclimatology, Turkey: 749-755.

Charloq \& H. Setiadi. 2005. Analisis stress air terhadap pertumbuhan bibit karet unggul (Hevea brasiliensis Muell. Arg). Jurnal Komunikasi Penelitian 17: 52- 56.

DaCosta, M. \& B. Huang. 2006. Osmotic adjustment associated with variation in Bentgrass tolerance to drought stress. J. Amer. Soc. Hort. Sci. 131: 338-344.

Din, J., S. U. Khan., I. Ali, \& A. R. Gurmani. 2011. Physiological and agronomic response of Canola varieties to drought stress. J. Anim. Plant Sci. 21: 78-82.

Dubois, M., K. A. Gilles., J. K. Hamilton., P. A. Rebers, \& F. Smith. 1956. Colorimetric method for determination of sugars and related substrances. Analytical Chemistry 28: 350-356. http://dx.doi.org/10.1021/ac60111a017

Efeoglu, B., Y. Ekmekci, \& N. Cicek. 2009. Physiological responses of three maize cultivars to drought stress and recovery. South African J. Bot. 75: 34-42. http://dx.doi. org/10.1016/j.sajb.2008.06.005

Farhad, M. S., A. M. Babak., Z. M. Reza., R. S. M. Hassan, \& T. Afshin. 2011. Response of proline, soluble sugars, photosynthetic pigments and antioxidant enzymes in potato (Solanum tuberasum L.) to different irrigation regimes in greenhouse condition. Australian J. Crop Science 5: 55-60.

Foth, H. 1984. Fundamentals of Soil Science. 7th Ed. John Wiley and Sons. New York.

Gholinezhad, E., A. Aynaband., A. H. Ghorthapeh., G. Noormohamadi, \& I. Bernousi. 2009. Study of the effect of drought stress on yield, yield components and harvest index of sunflower hybrid iroflor at different levels of nitrogen and plant population. Notulae Botanicae Horti Agrobotanici Cluj-Napoca 37: 85-94.

Hapsoh, S. Yahya., T. M. H. Oelim, \& B. S. Purwoko. 2006. Respons fisiologi beberapa genotipe kedelai yang bersimbiosis dengan MVA terhadap berbagai tingkat cekaman kekeringan. Hayati 13: 43-48.

ICT International. 2010. WP4 Dewpoint PotentiaMeter. http:// www.ictinternational.com.au/brochures/WP4man22. pdf [20-04-2010].

Karti, P. D. M. H. 2004. Pengaruh pemberian cendawan Mikoriza Arbuskula terhadap pertumbuhan dan produksi rumput Setaria splendida Stapf yang mengalami cekaman kekeringan. Med. Pet. 27: 63-68.

Khan, I. A., S. N. Mirza, S. M. Nizami, \& R. Hayat. 2008. Yield and nutrient uptake of Cenchrus ciliaris as affected by VA mycorrhizal inoculation. Sarhad J. Agric. 24: 289-292.

Khani, N. M. \& R. Heidari. 2008. Drought induced accumulation of soluble sugars and proline in two maize varieties. World Applied Sciences Journal 3: 448-453.

Kothari, S. K., H. Marschner, \& E. George. 1990. Effect of VAmycorrhizal fungi and rhizosphere microorganisms on root and shoot morphology, growth and water relations in maize. New Phytol. 116: 303-311. http://dx.doi.org/10.1111/ j.1469-8137.1990.tb04718.x

Kumar, R. R., K. Karajol, \& G. R. Naik. 2011. Effect of polyethylene glycol induced water stress on physiological and biochemical responses in Pigeonpea (Cajanus cajan L. Millsp.).
Recent Research in Science and Technology 3: 148-152.

Lannuci, A., M. Russo., L. Arena., N.D. Fonzo, \& P. Martiniello. 2002. Water deficit effect on osmotic adjustment and solute accumulation in leaves of annual clovers. European J. Agronomy 16: 111-112. http://dx.doi.org/10.1016/S11610301(01)00121-6

Li, Y., H. Zhao, B. Duan, H. Korpelainen, \& C. Li. 2011. Effect of drought and ABA on growth, photosynthesis and antioxidant system of Cotinus coggygria seed Lings under two different light conditions. Environmental and Experimental Botany 71: 107-113. http://dx.doi.org/10.1016/ j.envexpbot.2010.11.005

Liu, F. \& H. Stutzel. 2004. Biomass partitioning, specific leaf area, and water use efficiency of vegetable amaranth (Amaranthus spp.) in response to drought stress. Scientia Horticulturae 102: 15-27. http://dx.doi.org/10.1016/ j.scienta.2003.11.014

Martinez, J. P., H. Silva, J. F. Ledent, \& M. Pinto. 2007. Effect of drought stress on the osmotic adjustment, cell wall elasticity and cell volume of six cultivars of common beans (Phaseolus vulgaris L). Europ. J. Agronomy 26: 30-38. http:// dx.doi.org/10.1016/j.eja.2006.08.003

Masoudi, S. F., M. D. Abdollahi, M. R. Zardoshti, S. M. H. Rasouli, \& A. Tavakoli. 2011. Respon of proline, soluble sugars, photosynthetic pigments and antioxidant enzymes in potato (Solanum tuberosum L.) to different irrigation regimes in greenhouse condition. Australian Journal of Crop Science 5: 55-60.

Moaveni, P. 2011. Effect of water deficit stress on some physiological traits of wheat (Triticum aestivum). Agricultural Science Research Journal 1: 64-68.

Neumann, E. \& E. George. 2009. The effect of arbuscular mycorrhizal root colonization on growth and nutrient uptake of two different cowpea (Vigna unguiculata [L.] Walp.) genotypes exposed to drought stress. Emir. J. Food Agric. 21: 01-17.

Pirdashti, H., Z. T. Sarvestani, \& M. A. Bahmanyar. 2009. Comparison of physiological responses among four contrast rice cultivars under drought stress conditions. World Academy of Sci., Engineering and Tech. 49: 52-53.

Rahbarian. P., G. Afsharmanesh, \& M. H. Shirzadi. 2010. Effect of drought stress and manure on relative water content and cell membrane stability in dragonhead (Dracocephalum moldavica). Plant ecophysiology 2: 13-19.

Rascio, A., C. Platani, G. Scalfati, A. Tonti, \& N. DiFonzo. 1994. The accumulation of solutes and water binding strength in durum wheat. Plant Physiol. 90:715-721. http://dx.doi. org/10.1111/j.1399-3054.1994.tb02528.x

Sanchez, F. J., M. Manzanares, E.F. de Andres, J. L. Tenorio, \& L. Ayerbe. 1998. Turgor maintenance, osmotic adjustment and soluble sugar and proline accumulation in 49 pea cultivars in response to water stress. Field Crops Research 59: 225-235. http://dx.doi.org/10.1016/S0378-4290(98)00125-7

Sanchez, M. R., R. Aroca, Y. Munoz, R. Polon, \& J. M. R. Luzano. 2010. The arbuscular mycorrhizal symbiosis enhances the photosynthetic efficiency and the antioxidative response of rice plants subjected to drought stress. J. Plant Physiology 167: 862-869. http://dx.doi.org/10.1016/j.jplph.2010.01.018

Shao, H. B., L. Y. Chu., C. A. Jaleel, \& C. X. Zhao. 2008. Water defisit stress induced anatomical changes in higher plants. Comptes Rendus Biologies 331: 215-225. http://dx.doi. org/10.1016/j.crvi.2008.01.002

Slatyer, R. O. \& H. D. Barrs. 1965. Modification to the relative turgidity technique with notes on significance as an index of the internal water status of leaves. Arid Zone Res. 25:331-342.

Song, H. 2005. Effect of VAM on host plant in the condition of drought stress and its mechanisms. J. Biology 1: 44-48.

Stoyanov, Z. Z. 2005. Effect of water stress on leaf water rela- 
tions of young bean plants. J. Central Eur. Agriculture 6: 5-14.

Szabados, L. \& A. Savoure. 2009. Proline a multifunctional amino acid. Trends in Plant Science. Review. 15: 89-97.

Taiz, L. \& E. Zeiger. 2002. Plant Physiology. 3rd Ed. Sinauer Associates, Inc.

Vazquez, M. M., R. Azcon, \& J. M. Barea. 2001. Compatibility of a wild type and its genetically modified Sinorhizobium strain with two mycorrhizal fungi on Medicago species as affected by drought stress. Plant Science 161: 347358. http://dx.doi.org/10.1016/S0168-9452(01)00416-2

Verslues, P. E. \& S. Sharma. 2010. Proline metabolism and its implications for plant, environment interaction. American Society of Plant Biologists. 2010:e0140.10.1199/ tab.0140.http://dx.doi.org/10.1199/tab.0140 [10-11-2011].

Wilson, G. W. T. \& D. C. Hartnett. 1998. Interspecific variation in plant responses to mycorrhizal colonization in tallgrass prairie. American J. Bot. 85: 1732-1738. http://dx.doi. org $/ 10.2307 / 2446507$

Wu, Q. S. \& R. X. Xia. 2006. Arbuscular mycorrhizal fungi influence growth, osmotic adjustment and photosynthesis of citrus under well-watered and water stress conditions. J. Plant Physiology 163: 417-425. http://dx.doi. org/10.1016/j.jplph.2005.04.024
Wu, Q. S., R. X. Xia, Y. N. Zou, \& G. Y. Wang. 2007. Osmotic solute responses of mycorrhizal citrus (Poncirus trifoliata) seedling to drought stress. Acta Physiologiae Plantarum 29: 543-549. http://dx.doi.org/10.1007/s11738-007-0065-y

Wu, Q. S., R. X. Xia, \& Y. N. Zou. 2008. Improved soil structure and citrus growth after inoculation with three arbuscular mycorrhizal fungi under drought stress. European J. Soil Biology 44: 122-128. http://dx.doi. org/10.1016/j.ejsobi.2007.10.001

Yuan, G. F., C. G. Jia, Z. Li, B. Sun, L. P. Zhang, N. Liu, \& Q. M. Wang. 2010. Effect of Brassinosteroids on drought resistance and abscisic acid concentration in tomato under water stress. Scientia Horticulturae 126: 103-108. http:// dx.doi.org/10.1016/j.scienta.2010.06.014

Yue, Y., M. Zhang, J. Zhang, L. Duan, \& Z. Li. 2011. Arabidopsis LOS5/ABA3 overexpression in transgenic tobacco (Nicotiana tabacum cv. Xanthi-nc) result in enhanced drought tolerance. Plant Science 181: 405-411. http:// dx.doi.org/10.1016/j.plantsci.2011.06.010

Yousfia, N., S. Ines, G. Tahar, S. Arnould, \& A. Chedly. 2010. Effects of water deficit stress on growth, water relations and osmolyte accumulation in Medicago truncatula and M. populations. Comptes Rendus Biologies 333: 205-213. http://dx.doi.org/10.1016/j.crvi.2009.12.010 